\title{
IMPACT OF ELEVATED TEMPERATURE SCENARIOS ON POTATO LEAF DEVELOPMENT
}

\author{
NEREU A. STRECK ${ }^{1}$, LILIAN O. UHLMANN ${ }^{2}$, ALENCAR J. ZANON $^{3}$, \\ DILSON A. BISOGNIN ${ }^{4}$
}

\begin{abstract}
The objective of this study was to simulate the impact of elevated temperature scenarios on leaf development of potato in Santa Maria, RS, Brazil. Leaf appearance was estimated using a multiplicative model that has a non-linear temperature response function which calculates the daily leaf appearance rate (LAR, leaves day $^{-1}$ ) and the accumulated number of leaves (LN) from crop emergence to the appearance of the upper last leaf. Leaf appearance was estimated during 100 years in the following scenarios: current climate, $+1{ }^{\circ} \mathrm{C},+2{ }^{\circ} \mathrm{C},+3{ }^{\circ} \mathrm{C},+4{ }^{\circ} \mathrm{C}$ e $+5{ }^{\circ} \mathrm{C}$. The LAR model was estimated with coefficients of the Asterix cultivar in five emergence dates and in two growing seasons (Fall and Spring). Variable of interest was the duration (days) of the crop emergence to the appearance of the final leaf number (EM-FLN) phase. Statistical analysis was performed assuming a three-factorial experiment, with main effects being climate scenarios, growing seasons, and emergence dates in a completely randomized design using years (one hundred) as replications. The results showed that warmer scenarios lead to an increase, in the fall, and a decrease, in the spring growing season, in the duration of the leaf appearance phase, indicating high vulnerability and complexity of the response of potato crop grown in a Subtropical environment to climate change.
\end{abstract}

KEYWORDS: Solanum tuberosum, global warming, leaf appearance, agricultural crops, food security.

\section{IMPACTO DE CENÁRIOS DE AUMENTO DE TEMPERATURA NO DESENVOLVIMENTO FOLIAR DA BATATA}

RESUMO: O objetivo, neste trabalho, foi estimar o impacto de cenários de temperaturas elevadas no desenvolvimento foliar da cultura da batata, em Santa Maria-RS, Brasil. A emissão de folhas da cultura da batata foi estimada por um modelo multiplicativo com função de reposta não linear à temperatura que calcula a taxa diária de aparecimento de folhas (TAF, folhas dia $^{-1}$ ) e o número acumulado de folhas (NF) a partir da data de emergência da cultura até o surgimento da última folha. A emissão de folhas foi estimada em 100 anos de cada um dos cenários climáticos: clima atual, $+1{ }^{\circ} \mathrm{C},+2{ }^{\circ} \mathrm{C},+3{ }^{\circ} \mathrm{C},+4{ }^{\circ} \mathrm{C}$ e $+5{ }^{\circ} \mathrm{C}$. $\mathrm{O}$ modelo da TAF foi estimado com coeficientes da cultivar Asterix, em cinco datas de emergência e em duas estações de cultivo (Outono e Primavera). A variável de interesse foi duração (em dias) da fase de emergência das plântulas até o aparecimento da folha final (EM-FF). A análise estatística constou de um experimento trifatorial, com os fatores principais sendo cenários climáticos, estações de cultivo e datas de emergência no delineamento inteiramente casualizado, com anos (cem anos) como repetições. Observou-se que cenários mais quentes levam a um aumento, no cultivo de outono, e a uma diminuição, no cultivo de primavera, da duração da fase de emissão de folhas, indicando grande vulnerabilidade e complexidade da resposta da batata cultivada em ambiente Subtropical à mudança climática.

PALAVRAS-CHAVE: Solanum tuberosum, aquecimento global, emissão de folhas, culturas agrícolas, segurança alimentar.

\footnotetext{
${ }^{1}$ Eng ${ }^{\circ}$ Agrônomo, Professor Associado, Departamento de Fitotecnia, UFSM, Santa Maria - RS, Fone: (0XX55) 3220.8179, nstreck1@smail.ufsm.br.

${ }^{2}$ Graduanda em Agronomia, Departamento de Fitotecnia, UFSM, Santa Maria - RS, liliuhlmann@ yahoo.com.br.

${ }^{3}$ Eng ${ }^{\text {}}$ Agrônomo, Doutorando em Agronomia, UFSM, Departamento de Fitotecnia, Santa Maria - RS, alencarzanon@ yahoo.com.br.

${ }^{4}$ Eng ${ }^{\text {O }}$ Agrônomo, Professor Associado, Departamento de Fitotecnia, UFSM, Santa Maria - RS, dbisognin@ gmail.com.

Recebido pelo Conselho Editorial em: 31-1-2011

Aprovado pelo Conselho Editorial em: 4-3-2012
}

Eng. Agríc., Jaboticabal, v.32, n.4, p.689-697, jul./ago. 2012 


\section{INTRODUCTION}

Climate change is currently a major subject in scientific debates. Whereas the magnitude and the causes (if natural or anthropogenic, or both) of climate change are still under debate, there is an increasing consensus among scientists that climate is changing. A major signal of climate change is an increase in global temperature during the last five decades, referred as Global Warming (EASTERLING et al., 1997; VOSE et al., 2005; EASTERLING \& WEHNER, 2009), which is well documented in the latest Intergovernmental Panel on Climate Change report (IPCC, 2007). This increase in air temperature has also been reported in Brazil (MARENGO \& CAMARGO, 2008; SANSÍGOLO \& KAYANO, 2010). Furthermore, projections by the end of this century are for increases from 1.1 to $6.4{ }^{\circ} \mathrm{C}$ on air temperature in several locations worldwide, including Brazil (IPCC, 2007). This increase in global air temperature is due to a steady increase of greenhouse gases concentrations in the atmosphere, mainly carbon dioxide, since the industrial revolution and that were intensified after the 1950's (STRECK, 2005; IPCC, 2007).

Agriculture is a vulnerable sector to climate change that should face considerable changes and adaptations during and by the end of this century (IPCC, 2007). The response of agricultural crops to climate change scenarios has been addressed in several numerical and controlledenvironment experiments (WEISS et al., 2003; STRECK, 2005; STRECK et al., 2006). However, these studies have focused on studying the response of crop yield (WEISS et al., 2003; STRECK \& ALBERTO, 2006b) and phenology (ASSAD et al., 2004; STRECK et al., 2006; LAGO et al., 2008) to climate change, not on leaf development.

Leaf development, represented by the appearance of leaves, is an important part of the vegetative development of agricultural crops (HODGES, 1991). In annual crops, leaf appearance on the main stem begins at plant emergence and ends with the appearance of the uppermost leaf on the stem (also called the flag leaf), when the final leaf number (FLN) is defined. During the vegetative development, leaves appear at a given rate, and integrating the rate of leaf appearance over time results in the number of accumulated leaves $(\mathrm{LN})$ on a stem until the flag leaf appearance (STRECK et al., 2003a; XUE et al., 2004). The LN is an excellent measure of vegetative development, and it is related to some developmental stages, like tuber initiation in potato (HELDWEIN et al., 2009), and to the increase of leaf area index (LAI). The LAI is responsible for intercepting solar radiation necessary to crop photosynthesis, which ultimately defines crop growth and yield (STRECK et al., 2003b). Changes in meteorological variables under climate change scenarios may affect several processes of plant growth and development, and therefore determining how basic processes, such as leaf development, are affected is crucial for understanding how crops respond to global warming and to fully resolve mitigation approaches for the agricultural chain in future climates.

Potato (Solanum tuberosum), Solanaceae family, is native of the Andes Mountains in South America and ranks fourth as the most important crop for food production worldwide, after wheat, rice and maize (NYENDE et al., 2005). Potato is a major staple food in different cultures and countries, because of its nutritional properties, gastronomic possibilities and low costs of tubers (ABBA, 2010). In southern Brazil (Rio Grande do Sul, Santa Catarina and Paraná), potato is grown in regions with Subtropical and Temperate climate (HELDWEIN et al., 2009). In Subtropical regions, potato can be produced in two growing seasons (Fall and Spring) whereas in Temperate regions, potato is produced in a single growing season during Summer (HELDWEIN et al., 2009).

Potato crop plays an important role in small farms in the state of Rio Grande do Sul. Most of the potato production area in this State is located in Subtropical regions (HELDWEIN et al., 2009). Therefore, understanding how potato crop can be affected by global warming is important as a considerable number of people may be affected, mainly in Subtropical regions where temperatures range near the thresholds for potato growth and development (HELDWEIN et al., 2009). In potato, leaf appearance phase overlaps the tuberization phase (HELDWEIN et al., 2009) and any change in leaf development dynamics caused by global warming can potentially impact tuber growth, but such studies have not been addressed in Brazil, which constituted the rationale for this study. 
The objective of this study was to simulate the impact of elevated temperature scenarios on leaf development of potato in Santa Maria, RS, Brazil.

\section{MATERIAL AND METHODS}

This numerical study was conducted for conditions of Santa Maria, RS (latitude $29^{\circ} 43^{\prime} \mathrm{S}$, longitude $53^{\circ} 43^{\prime} \mathrm{N}$, altitude $95 \mathrm{~m}$ ). Santa Maria is located in the Central Region of the State of Rio Grande do Sul and has a subtropical warm and humid climate, Cfa formula according to the Köeppen System (KUINCHTNER \& BURIOL, 2001), and representative of a major potato production area in the State of Rio Grande do Sul (BISOGNIN \& STRECK, 2009).

Leaf development was simulated with the leaf appearance model proposed by WANG \& ENGEL (1998), hereafter named the WE model. The general form of the WE model is:

$$
\mathrm{LAR}=\mathrm{LAR}_{\max } \mathrm{f}(\mathrm{T})
$$

where LAR is the daily leaf appearance rate (leaves day ${ }^{-1}$ ), $\mathrm{LAR}_{\max }$ is the maximum daily leaf appearance rate (leaves day $^{-1}$ ) and $\mathrm{f}(\mathrm{T})$ is a dimensionless non-linear temperature response function that varies from zero to one. The $\mathrm{f}(\mathrm{T})$ is a version of the beta function defined as (WANG \& ENGEL, 1998):

$$
\begin{array}{ll}
f(T)=\left[2\left(T-T_{\min }\right)^{\alpha}\left(T_{o p t}-T_{\min }\right)^{\alpha}-\left(T-T_{\min }\right)^{2 \alpha}\right] /\left(T_{o p t}-T_{\min }\right)^{2 \alpha} & \text { for } T_{\min } \leq T \leq T_{\max } \\
f(T)=0 & \text { for } T<T \min \text { or } T>T \max \\
\alpha=\ln 2 / \ln \left[\left(T_{\max }-T_{\min }\right) /\left(T_{o p t}-T_{\min }\right)\right] &
\end{array}
$$

where Tmin, Topt and Tmax are the cardinal temperatures (minimum, optimum and maximimum, respectively) for leaf appearance and $\mathrm{T}$ is the mean air temperature, calculated as the arithmetic average of daily minimum and maximum air temperatures. The accumulated number of leaves (LN) is estimated by adding up LAR, i.e. $\mathrm{LN}=\Sigma \mathrm{LAR}$, from crop emergence to the appearance of the flag leaf. The WE model was calibrated and tested previously in Rio Grande do Sul conditions (STRECK et al., 2007), and the coefficients LAR $\mathrm{max}_{\min }, \mathrm{T}_{\min }, \mathrm{T}_{\mathrm{opt}}$ and $\mathrm{T}_{\max }$ are genotype-specific. In this study we used the coefficients for Asterix, a cultivar widely used by potato growers in the State of Rio Grande do Sul: $\mathrm{LAR}_{\max }=0.872$ leaves day ${ }^{-1}, \mathrm{~T}_{\min }=7^{\circ} \mathrm{C}, \mathrm{T}_{\mathrm{opt}}=21^{\circ} \mathrm{C}$, and $\mathrm{T}_{\max }=30{ }^{\circ} \mathrm{C}(\mathrm{STRECK}$ et al., 2007).

Six climate scenarios were used in this study: current climate, $+1{ }^{\circ} \mathrm{C},+2{ }^{\circ} \mathrm{C},+3{ }^{\circ} \mathrm{C},+4{ }^{\circ} \mathrm{C}$ and $+5^{\circ} \mathrm{C}$. This wide range of elevated temperature scenarios used in this study include the range of climate change scenarios suggested by the IPCC (2007) for the end of this century, varying from a more optimist to a more pessimist scenarios.

Each of the scenarios had one hundred years and were created with the LARS-WG weather generator (SEMENOV et al., 1998) using a data set of meteorological data from 1969 to 2003 measured at the Meteorological Station of the Brazilian National Weather Service $\left(8^{\underline{0}}\right.$ DISME/INMET) at Santa Maria, RS, and increasing linearly daily with minimum and maximum temperatures. An example of two of these scenarios (Current and $+5^{\circ} \mathrm{C}$ ) during the two growing seasons is presented in Figure 1. These synthetic scenarios have been used previously (STRECK \& ALBERTO, 2006a, b; LAGO et al., 2008). 

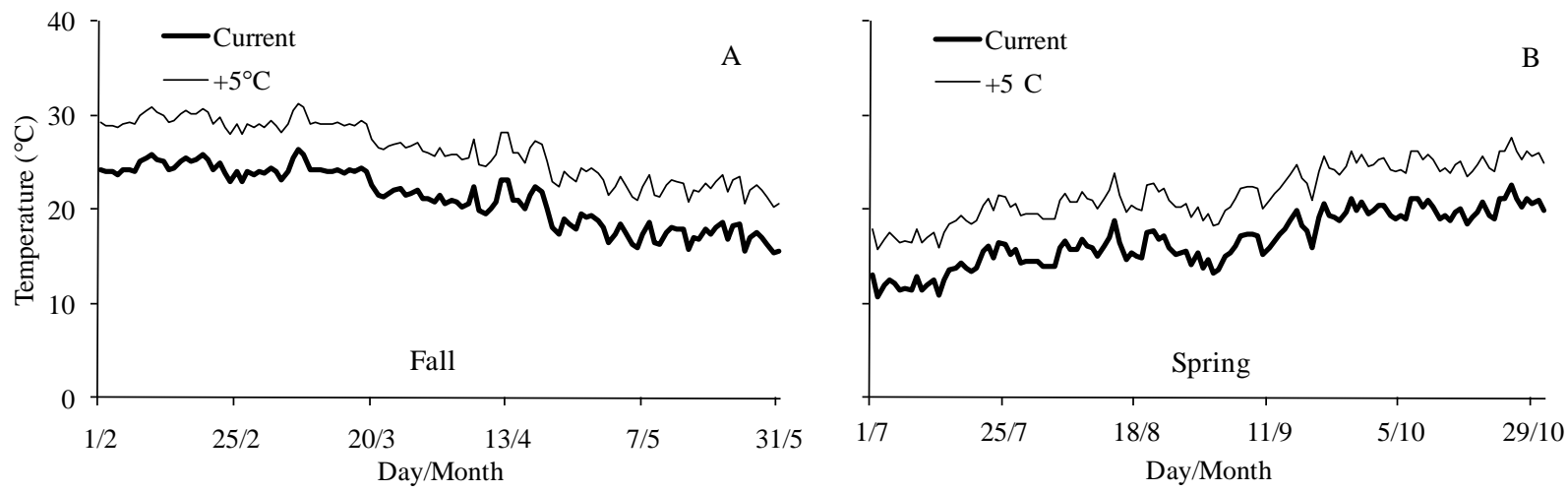

FIGURE 1. Mean daily temperature of the first 10 years of two synthetic scenarios (Current and $\left.+5{ }^{\circ} \mathrm{C}\right)$ during Fall $(01 / 02-31 / 05)$ and Spring $(01 / 07-31 / 10)$ growing seasons used in the study.

For each of the one hundred years scenarios, the LN on the main stem was estimated from emergence to the appearance of the flag leaf. Two typical growing seasons for potato in this location were considered (Fall growing season = "safrinha", and Spring growing season = "safra"), according to HELDWEIN et al. (2009). In each growing season, five emergence dates were considered according to STRECK et al. (2006): (day/month) 6/02, 13/02, 20/02, 27/02 and 06/03 for the Fall growing season and 26/07, 02/08, 09/08, 16/08 and 23/08 for the Spring growing season. It was assumed that the potato crop was irrigated, as the coefficients of the cultivar Asterix were obtained under irrigated conditions (STRECK et al., 2007).

This assumption is reasonable for this location as currently local potato growers use to irrigate their potato fields when precipitation is below normal. Final leaf number was assumed 20 leaves in the Fall growing season and 24 leaves in the Spring growing season (STRECK et al., 2007).

Data were analyzed in terms of the duration (days) of the emergence to the appearance of the flag leaf or final leaf number (EM-FLN) phase. Statistical analysis consisted of performing ANOVA and assuming a three-factorial experiment, with main effects being climate scenarios (six levels), growing season (two levels), and emergence dates (five levels) in a completely randomized design, with years (one hundred) as replications.

Means of the duration of the EM-FLN phase were distinguished using the Tukey test at 5\% probability, i.e., treating all factors as qualitative treatments, including the climate scenarios, each of them representing a set of atmospheric conditions resulting from physical and economical scenarios projected by the IPCC (2007) by the end of this century.

\section{RESULTS AND DISCUSSION}

Analysis of variance indicated that main effects (climate scenarios, growing seasons and emergence dates) and the three interactions (climate scenarios $\mathrm{x}$ growing seasons $\mathrm{x}$ emergence dates) were all significant (Table 1). Therefore, analysis with the Tukey test was split accordingly, i.e. the effect of climate scenarios was tested within growing seasons and within emergence dates (Figure 2). Among the three main effects, mean square for growing season was the largest and for emergence dates was the smallest (Table 1), indicating that growing season (Fall and Spring) has a larger effect on potato leaf development than emergence dates. The mean square for climate scenarios was intermediate but high $\left(17,992.7\right.$ days $\left.^{2}\right)$, indicating that leaf development in potato is also highly sensitive to global warming. 
TABLE 1. Mean squares from the ANOVA of the duration of the emergence to the appearance of the flag leaf phase for the potato cultivar Asterix.

\begin{tabular}{lrcc}
\hline Source of Variation & df & Mean Square $\left(\right.$ days $\left.^{2}\right)$ & Probability \\
\hline Climate scenarios (A) & 5 & $17,992.7$ & $<0.0001$ \\
Growing season (B) & 1 & $22,442.1$ & $<0.0001$ \\
Emergence date (C) & 4 & $6,599.1$ & $<0.0001$ \\
$\mathrm{~A}^{*} \mathrm{~B}$ & 5 & $34,599.0$ & $<0.0001$ \\
$\mathrm{~A}^{*} \mathrm{C}$ & 20 & $1,34.9$ & $<0.0001$ \\
$\mathrm{~B} * \mathrm{C}$ & 4 & $1,917.9$ & $<0.0001$ \\
$\mathrm{~A}^{*} \mathrm{~B} * \mathrm{C}$ & 20 & 416.1 & $<0.0001$ \\
\hline
\end{tabular}

Df - degree of freedom

For the Fall growing season, the duration of the EM-FLN phase was lower under current climate and increased in the elevated temperature scenarios in all emergence dates (Figure 2A). Within each scenario, the duration decreased as crop emergence was delayed, and shortening of the EM-FLN phase in later emergence dates was more evident as temperature increased in the climate scenarios. The lowest duration was 26 days in the $06 / 03$ emergence date under current climate and the longest duration was 63 days in the $06 / 02$ emergence date in the $+5{ }^{\circ} \mathrm{C}$ scenario.

For the Spring growing season, the duration of the EM-FLN phase showed an opposite response, with the longest duration in current climate scenario and a decrease in the duration in the elevated temperature scenarios, mainly in the increases up to $+3{ }^{\circ} \mathrm{C}$ (Figure 2B). Within each scenario, the duration of the EM-FLN phase decreased as crop emergence was delayed in current climate and in the $+1{ }^{\circ} \mathrm{C},+2{ }^{\circ} \mathrm{C},+3{ }^{\circ} \mathrm{C}$ and $+4{ }^{\circ} \mathrm{C}$ scenarios. The lowest duration was 32 days in the $23 / 08$ emergence date in the $+3{ }^{\circ} \mathrm{C}$ scenario and the longest duration was 41 days in the $26 / 07$ emergence date under current climate scenario.

The increase in the duration of the EM-FLN phase as temperature increased in the climate scenarios simulated in the Fall growing season in all crop emergence dates (Figure 2A) was because there were more days during the leaf appearance phase with mean daily temperature above the optimum temperature for LAR in potato $\left(21^{\circ} \mathrm{C}\right)$ in the elevated temperature scenarios compared to current climate. In the LAR model (equation 1), supra-optimum temperatures decrease daily LAR, because in this range of the response the $f(T)$ is lower than one (equation 2). This was not the case for the Spring growing season (Figure 2B), when mean daily temperature was not above $21{ }^{\circ} \mathrm{C}$ very often, even in the $+4{ }^{\circ} \mathrm{C}$ and $+5{ }^{\circ} \mathrm{C}$ scenarios. These results are in agreement with STRECK et al. (2006) who found that tuber initiation in potato is delayed in elevated temperature scenarios during the fall growing season, whereas tuber initiation was hastened during the spring growing season. Results also agree with observed results by STRECK et al. (2007) that leaf appearance in potato grown during summer months in Subtropical climate was delayed compared to potato grown in the spring.

From Figure 2, a general response to climate change that can be depicted is that the duration of the EM- FLN phase is less sensitive to elevated temperature in the Spring growing season (Figure 2B) compared to the Fall growing season (Figure 2A). These results indicate, firstly, a greater vulnerability of potato grown in fall compared to potato grown in spring in this Subtropical environment and, secondly, indicate a high complexity in the response of leaf development to climate change in potato in this location. 

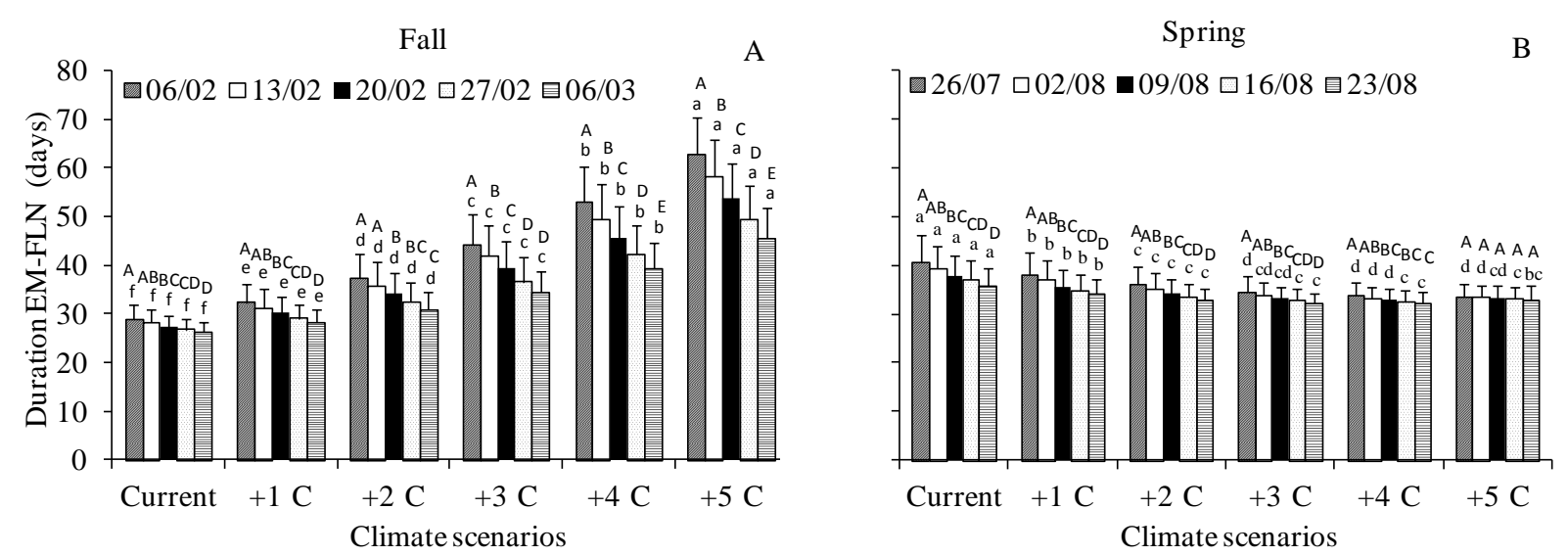

FIGURE 2. Duration (days) of the emergence to final leaf number (EM-FLN) phase of potato, Asterix cultivar, simulated in two growing seasons $(\mathrm{A}=$ Fall, $\mathrm{B}=\mathrm{Spring})$ in five emergence dates (indicated in each panel - day/month) as a function of different climate scenarios (current climate and elevated temperature scenarios). Each column is the mean of one hundred years of simulations and error bars represent one standard deviation of the mean. Uppercase letters compare emergence dates within climate scenarios and lowercase letter compare climate scenarios within each emergence date. Bars linked by different letters are different according to the Tukey test at $5 \%$ probability.

An increase in the duration of leaf appearance under warmer climate, as simulated for the fall growing season in this location, has implications both on a physiological basis and from a crop management perspective. Physiologically, a greater duration of the leaf appearance phase in a warmer climate means that plant tissue is exposed to greater respiration rates for a longer period, leading to lower net photosynthesis on a canopy basis (TAIZ \& ZEIGER, 2004), which has direct impact on photoassimilates available for tuber growth. For crop management, a longer leaf appearance rate phase associated with a warmer environment may increase the potential and the severity of potato leaf diseases (HELDWEIN et al., 2009), which may increase the number of fungicide sprayings, which in turn increases both management costs and environment impacts in commercial potato fields in Rio Grande do Sul.

A major challenge in the studies of assessing the effect of the climate changes on agriculture crops is to understand how basic growth and development processes can be affected by the projected climate change. This study attempted to address such a fundamental question in potato and the results obtained here are an additional example on how vulnerable agriculture crops are to climate change. Potato breeding programs may use this information to incorporate traits for screening potato genotypes with greater tolerance to high temperatures mainly for Subtropical locations, where temperatures are, even currently, near the edge of the upper threshold and are expected to exceed the threshold very often if global warming takes place as projected by the end of this century (IPCC, 2007). Another strategy to mitigate the effects of high temperatures on potato would be the migration of potato production areas up to higher areas in the mountains, such as has been suggested for coffee crops in Southern Brazil (ASSAD et al., 2004). However, each of these strategies may take years until adapted and accepted by local potato growers. The implications and challenges of these adaptations strategies have to be in the agenda of current decision makers and researcher teams in Brazil.

A warmer atmosphere in the future will also very likely have higher $\mathrm{CO}_{2}$ (IPCC, 2007). The effect of elevated $\mathrm{CO}_{2}$ was not taken into account in this study because no report on the effect of $\mathrm{CO}_{2}$ on potato leaf appearance was found. A general assumption is that stomata conductance is lower and leaf temperature is higher under elevated $\mathrm{CO}_{2}$ (STRECK, 2005), and therefore, the effect of elevated temperature on leaf development may be higher than the effect simulated in this study. The magnitude of this effect still needs to be measured in potato for incorporating a $\mathrm{CO}_{2}$ response in the WE model. 


\section{CONCLUSIONS}

Warmer climate scenarios in Subtropical regions lead to an increase in the duration of leaf appearance phase (leaf development was delayed) in potato grown in the fall growing season and to a decrease in the duration (leaf development is accelerated) in the spring growing season, with greater response in the fall. These results indicate high vulnerability and complexity of the response of potato crop to global warming when grown in a Subtropical environment.

\section{ACKNOWLEGMENTS}

Authors thank to Conselho Nacional de Desenvolvimento Técnico e Científico (CNPq) of the Ministry of Science and Tecnology for financial support (Bolsa de Produtividade em Pesquisa and Bolsa PIBIC/CNPq/UFSM).

\section{REFERENCES}

ABBA. Associação Brasileira da Batata. A batata como alimento. Itapetininga. Disponível em: <http://www.abbabatatabrasileira.com.br>. Acesso em: 21 abr. 2010.

ASSAD, E.D.; PINTO, H.S.; JUNIOR, J.Z.; ÁVILA, A.M.H. Impacto das mudanças climáticas no zoneamento agroclimático do café no Brasil. Pesquisa Agropecuária Brasileira, Brasília, v.39, n.11, p.1057-1064, 2004. Disponível em: <http://www.scielo.br/scielo.php?script=sci_arttext\&pid=S0100204X2004001100001\&lng=pt\&nrm=iso>. Acesso em: 1 nov. 2010.

BISOGNIN, D.A.; STRECK, N.A. Desenvolvimento e manejo das plantas para alta produtividade e qualidade da batata. Itapetininga: Associação Brasileira da Batata, Itapetininga, v.1, 2009. 30 p.

EASTERLING, D.R.; HORTON, B.; JONES, P.D.; PETERSON, T.C.; KARL, T.R.; PARKED, D.E.; SALINGER, M.J.; RAUVAYEV, V.; PLUMMER, N.; JAMASON, P.; FOLLAND, C.K.. Maximum and minimum temperature trends for the globe. Science, Washington, v.277, n.5324, p.364-367, 1997. Disponível em: <http://www.met.sjsu.edu/ jin/METR112/paper/Scienceminmax.pdf >. Acesso em: 5 nov. 2010.

EASTERLING, D.R.; WEHNER, M.F. Is the climate warming or cooling? Geophysical Research Letters, Florida Avenue N.W. Washington, v.36, n.3, p. L 08706, 2009. Disponível em: <http://www.esrl.noaa.gov/psd/csi/images/GRL2009_ClimateWarming.pdf>. Acesso em: 5 nov. 2010.

HELDWEIN, A.B.; STRECK, N.A.; BISOGNIN, D.A. Cultivos temporários: batata. In: MONTEIRO, J.E.B.A. (Org.). Agrometeorologia dos cultivos: o fator meteorológico na produção agrícola. Brasília: INMET. 2009. p.91-108.

HODGES, T. Predicting crop phenology. Boca Raton: CRC, 1991. 233 p.

IPCC. Intergovernmental Panel on Climate Change. Climate change 2007: the physical science basis. New York: Cambridge University Press, 2007. 996 p.

KUINCHTNER, A.; BURIOL, G.A. Clima do Estado do Rio Grande do Sul segundo a classificação climática de Köeppen e Thornthwaite. Disciplinarum Scientia, Santa Maria, v.2, n.1, p.171-182, 2001. Disponível em: <http://sites.unifra.br/Portals/36/tecnologicas/2001/clima.pdf>. Acesso em: 30 out 2010.

LAGO, I.; STRECK, N.A.; ALBERTO, C.M.; OLIVEIRA, F.B.; PAULA, G.M.de. Impact of increasing mean air temperature on the development of rice and red rice. Pesquisa Agropecuária Brasileira, Brasília, v. 43, n.11, p.1441-1448, 2008. Disponível em:

<http://www.scielo.br/scielo.php?script=sci_arttext\&pid=S0100204X2008001100001\&lng=pt\&nrm=iso $>$. Acesso em: 18 out. 2010.

MARENGO, J.A.; CAMARGO, C. Surface air temperature trends in Southern Brazil for 1960-2002. International Journal of Climatology, Malden, v.28, n.7, p.893-904, 2008. Disponível em: < http://onlinelibrary.wiley.com/doi/10.1002/joc.1584/abstract>. Acesso em: 5 nov 2010. 
NYENDE, A.B.; SCHITTENHELM, S.; MIX-WAGNER, G.; GREEF, J.M. Yield and canopy development of field grown potato plants derived from synthetic seeds. European Journal of Agronomy, Amsterdam, v. 22, n.2, p.175-184, 2005. Disponível em: <http://www.sciencedirect.com/science?_ob=ArticleURL\&_udi=B6T67-4CBVVRR$1 \&$ user=10\&_coverDate $=02 \% 2 \mathrm{~F} 28 \% 2 \mathrm{~F} 2005 \& \_$rdoc $=1 \&$ fmt $=$ high \&_orig $=$ search \&_origin $=$ search $\&$. sort $=\mathrm{d} \&$ _docanchor $=\&$ view $=c \& \_s e a r c h S t r I d=1624461272 \&$ rerunOrigin $=$ google $\&$ acct $=C 000050221$ \&_version $=1 \&$ _urlVersion $=0 \& \_u s e r i d=10 \& m d 5=778876203 \mathrm{a} 882 \mathrm{c} 3 \mathrm{~b} 9 \mathrm{cc} 767 \mathrm{fc} 38 \mathrm{efb} 075 \&$ searchtype $=\mathrm{a}>$ . Acesso em: 20 out. 2010.

SANSÍGOLO, C.A.; KAIANO, M.T. Trends of seasonal maximum and minimum temperatures and precipitation on Southern Brazil for the 1913-2006 period. Theoretical and Applied Climatology, Vienna, v.101, n.1-2, p.209-216, 2010. Disponível em: < www.springerlink.com/index/jg1h45k02687815t.pdf >. Acesso em: 05 nov. 2010.

SEMENOV, M.A.; BROOKS, R.J.; BARROW, E.M.; RICHARDSON, C.W. Comparison of the WGEN and LARS-WG stochastic weather generators for diverse climates. Climate Research, United Kingdom, v.10, n.1, p.95-107, 1998. Disponível em: < http://www.rothamsted.bbsrc.ac.uk/masmodels/SupportFiles/Papers/ComparisonWGENandLARSWG.pdf>. Acesso em: 5 nov. 2010.

STRECK, N.A. Climate change and agroecosystems: the effect of elevated $\mathrm{CO}_{2}$ and temperature on crop growth, development, and yield. Ciência Rural, Santa Maria, v. 35, n. 3, p.730-740, 2005. Disponível em: <http://www.scielo.br/scielo.php?script=sci_arttext\&pid=s0103-84782005000300041 >. Acesso em: 1 nov 2010.

STRECK, N.A.; ALBERTO, C.M. Estudo numérico do impacto da mudança climática sobre o rendimento de trigo, soja e milho. Pesquisa Agropecuária Brasileira, Brasília, v. 41, n.9, p.1351-1359, 2006b. Disponível em: <http://webnotes.sct.embrapa.br/pdf/pab2006/09/41n09a02.pdf.> Acesso em: 2 nov. 2010.

STRECK, N.A.; ALBERTO, C.M. Simulação do impacto da mudança climática sobre a água disponível do solo em agroecossistemas de trigo, soja e milho em Santa Maria, RS. Ciência Rural, Santa Maria, v.36, n.2, p.424-433, 2006a. Disponível em:

<http://homologa.ambiente.sp.gov.br/proclima/artigos_dissertacoes/artigos_portugues/simulacaodoimpact odamudancaclimatica.pdf $>$. Acesso em: 5 nov. 2010.

STRECK, N.A.; LAGO, I.; ALBERTO, C.M.; BISOGNIN, D.A. Simulação do desenvolvimento da batata (Solanum tuberosum L.) cultivar Asterix em cinco cenários de mudanças climáticas em Santa Maria, RS. Bragantia, Campinas, v. 65, n.4, p.693-702, 2006. Disponível em: $<$ http://www.scielo.br/scielo.php?script=sci_arttext\&pid=S0006-87052006000400021>. Acesso em: 5 nov. 2010.

STRECK, N.A.; LAGO, I.; PAULA, F.L.M.; BISOGNIN, D.A.; HELDWEIN, A.B. Improving predictions of leaf appearance in field grown potato. Scientia Agricola, Piracicaba, v.64, n.1, p.12-18, 2007. Disponível em: <http://www.scielo.br/pdf/sa/v64n1/a02v64n1.pdf>. Acesso em: 6 nov. 2010.

STRECK, N.A.; WEISS, A.; BAENZIGER, P.S.; XUE, Q. Incorporating a chronology response into prediction of leaf appearance rate in winter wheat. Annals of Botany, Oxford, v.92, n.2, p.181-190, $2003 \mathrm{a}$. Disponível em: <http://aob.oxfordjournals.org/cgi/reprint/92/2/181〉. Acesso em: 5 nov. 2010.

STRECK, N.A.; WEISS, A.; XUE, Q.; BAENZIGER, P.S. Improving predictions of developmental stages in winter wheat: a modified Wang and Engel model. Agricultural and Forest Meteorology, Amsterdam, v.115, n.3-4, p.139-150, 2003b. Disponível em: $<$ http://www.sciencedirect.com/science?_ob=ArticleURL\&_udi=B6V8W-47DT8TW $1 \& \_u s e r=687358 \& \_r d o c=1 \& \_\mathrm{fmt}=\& \_$orig $=$search \&_sort $=\mathrm{d} \& \_\mathrm{d}$ ocanchor $=\&$ view $=c \& \_$searchStrId $=956236250 \& \_$rerunOrigin $=$google \&_acct $=$ C000037899\&_version $=1 \& \_u r l$ Version $=0$ \&_userid=687358\&md5=dd18c78a46e01ba4eb48db12813d0585>. Acesso em: 22 out 2010. 
TAIZ, L.; ZEIGER, E. Fisiologia vegetal. 4.ed. Porto Alegre: Artemed, 2004. 719p.

VOSE, R.S.; EASTERLING, D.R.; GLEASON, B. Maximum and minimum temperature trends for the globe: an update through 2004. Geophysical Research Letters, Washington, v.32, n.23, p.L23822, 2005. Disponível em: <ftp: //ftp.ncdc.noaa.gov/pub/data/papers/200686amsp4.1rvfree.pdf>. Acesso em: 25 out. 2010.

WANG, E.; ENGEL, T. Simulation of phenological development of wheat crops. Agricultural Systems, Netherlands, v. 58, n.1, p.1-24, 1998. Disponível em:

<http://www.sciencedirect.com/science/article/B6T3W-3V2F8WS-

1/2/4c8139487f8dc65a17b7193f46f6da9a>. Acesso em: 1 nov. 2010.

XUE, Q.; WEISS, A.; BAENZIGER, P.S. Predicting leaf appearance in field-grown winter wheat: evaluating linear and non-linear models. Ecological Modelling, Amsterdam, v.175, n.3, p.261-270, 2004. Disponível em: <http://www.sciencedirect.com/science?_ob=ArticleURL\&_udi=B6VBS-4BJX1HYJ\&_user=687358\&_coverDate $=07 \% 2 \mathrm{~F} 15 \% 2 \mathrm{~F} 2004 \&$ \&doc $=1 \&$ fmt=high $\&$ _orig $=$ search \&_origin $=$ searc

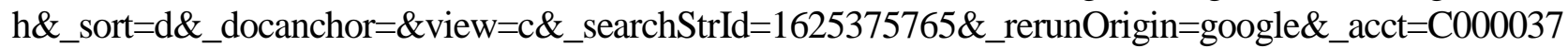
899\&_version=1\&_urlVersion=0\&_userid=687358\&md5=1efff37805ca510a1b4e1600f8ff9a70\&searcht ype=a>: Acesso em: 16 out. 2010.

WEISS, A.; HAYS, C.J.; JAEPIL, W. Assessing winter wheat responses to climate change scenarios: a simulation study in the U.S. Great Plains. Climatic Change, Vandoeuvre-lès-Nancy, v.58, n.1-2, p.119147, 2003. Disponível em: <http://www.springerlink.com/index/j62n71106q25752h.pdf>. Acesso em: 27 out. 2010. 